\title{
Strategi Guru Bimbingan Konseling Mengatasi Kesulitan Belajar Siswa SMP Negeri 46 Kerinci
}

\author{
Ahmad Zuhdi, Nurhalis, Mulyarti
}

\begin{abstract}
Abstrak
Artikel ini mengangkat judul "Strategi Guru Bimbingan Konseling Mengatasi Kesulitan Belajar Siswa SMP Negeri 46 Kerinci”. Penting kiprah seorang guru dalam membantu siswa mengatasi kesulitan atau hambatan ketika mengikuti pembelajaran serta perkembangannya, tentu sebagai pendidik dituntut memiliki pemahaman yang bijak dalam mengenal keluhan para siswanya, mengenali aspek-aspek potensi yang dimiliki dan kekurangan atau kelemahannya.
\end{abstract}

Kata kunci : Strategi, Guru, Bimbingan, Konseling

\section{A. Pendahuluan}

Dalam Undang-undang Nomor 20 Tahun 2003 Tentang Sistem Pendidikan Nasional, pendidikan diartikan sebagai usaha sadar dan terencana untuk mewujudkan suasana belajar dan proses pembelajaran agar peserta didik secara aktif mengembangkan potensi dirinya untuk memiliki kekuatan spiritual keagamaan, pengendalian diri, kepribadian, kecerdasan akhlak mulia, serta keterampilan yang diperlukan dirinya, masyarakat, bangsa dan negara. ${ }^{1}$ Lebih lanjut, mengenai fungsi pendidikan dinyatakan bahwa Pendidikan Nasional berfungsi mengembangkan kemampuan dan membentuk watak serta peradaban bangsa yang bermartabat dalam rangka mencerdaskan kehidupan bangsa, bertujuan untuk berkembangnya potensi peserta didik agar menjadi manusia yang beriman dan bertakwa kepada Tuhan Yang Maha Esa, berakhlak mulia, sehat, berilmu, cakap, kreatif, mandiri dan menjadi warga negara yang demokratis serta bertanggung jawab. ${ }^{2}$

Selain sebagai pendidik dan pengajar, guru juga punya peran sebagai pembimbing. Perkembangan anak tidak selalu mulus dan lancar, adakalnya lambat dan mungkin juga berhenti sama sekali. Dalam situasi seperti itu mereka perlu mendapatkan bantuan atau bimbingan. Agar tercapai kondisi seperti itu, guru perlu banyak mendekati para siswa, membina hubungan yang

\footnotetext{
1 Departemen Pendidikan Nasional, Undang-undang Republik Indonesia Nomor 20 Tahun 2003 Sistem Pendidikan Nasional, (Jakarta : Departemen Pendidikan Nasional, 2003), h. 4

2 Surya Dharma, Bimbingan dan Konseling di Sekolah, (Jakarta : PMTK, 2008), h. 1
} 
lebih dekat dan lebih akrab, melakukan pengamatan serta mengadakan dialog langsung.

\section{B. Pentingnya Layanan}

Perlunya program layanan bimbingan yang disebut bimbingan konseling, Karena dengan adanya layanan bimbingan konseling seorang siswa akan merasa mempunyai tempat untuk mengadukan semua permasalahan yang dihadapi, baik diluar kelas maupun di luar kelas. Dalam hal ini semua guru mempunyai tanggung jawab yang sama dengan guru bimbingan konseling dalam menyelesaikan permasalahan siswa, tapi dalam hal ini yang lebih bisa memahami kondisi psikis seorang anak adalah guru bimbingan konseling yang memang sudah menjadi bidangnya. Menurut Miller yang dikutip oleh Surya Dharma mengatakan bahwa sebagai berikut :

Bimbingan adalah proses bantuan terhadap individu untuk mencapai pemahan diri dan pengarahan diri yang dibutuhkan untuk melakukan penyesuaian diri secara maksimum kepada sekolah, keluarga, serta masyarakat. ${ }^{3}$ Sedangkan menurut Rogers yang dikutip oleh Surya Dharma menjelaskan pengertian konseling yang mengatakan bahwa : Konseling adalah serangkaian kontak atau hubungan bantuan langsung dengan individu dengan tujuan memberikan bantuan kepadanya dalam merubah sikap dan tingkah lakunya. ${ }^{4}$ Dengan demikian jelaslah, bahwa konseling merupakan salah satu teknik pelayanan bimbingan secara keseluruhan, yaitu dengan cara memberikan bantuan secara individual (face to face relationship). Bimbingan tanpa konseling ibarat pendidikan tanpa pengajaran atau perawatan tanpa pengobatan. Kalaupun ada perbedaan di antara keduanya hanyalah terletak pada tingkatannya.

Dari hasil pengamatan penulis di SMP Negeri 46 Kerinci, pembelajaran hanya berpusat pada guru, siswa hanya mendengar, memperhatikan, mengerjakan tugas-tugas yang diberikan guru serta guru dalam belajar hanya memakai metode ceramah dan tanya jawab. Hal ini menyebabkan siswa kurang kreatif dan tidak berinisiatif untuk berusaha mempelajari sendiri materi pelajaran yang akan dipelajari. Selain itu, hasil belajar yang diperoleh siswa masih rendah. Berdasarkan hasil pengamatan penulis, hasil belajar siswa SMP Negeri 46 Kerinci masih rendah rata-rata siswa mendapatkan nilai 62 kebawah sedangkan nilai rata-rata ketuntasan pembelajaran yang telah ditetapkan oleh SMP Negeri 17 Kerinci yaitu diatas 65 setiap mata pelajaran, ini disebabkan karena pembelajaran hanya berpusat pada guru, siswa hanya mendengar, memperhatikan, mengerjakan tugas-tugas yang diberikan guru, serta guru dalam mengajar hanya memakai metode ceramah dan tanya jawab. Berdasarkan latar belakang masalah di atas, maka masalah pokok pada penelitian ini adalah sebagai berikut : Bagaimana bentuk kesulitan belajar

3 Surya Dharma, Op, Cit., h. 5

lbid., h. 6 
siswa SMP Negeri 46 Kerinci? Apa saja faktor pendukung dan penghambat guru bimbingan konseling dalam mengatasi kesulitan belajar siswa SMP Negeri 46 Kerinci? Bagaimana strategi guru bimbingan konseling dalam mengatasi kesulitan belajar siswa SMP Negeri 46 Kerinci?

\section{Bentuk Kesulitan Belajar Siswa di Sekolah Menengah Pertama Negeri (SMP N) 46 Kerinci}

Guru mata pelajaran adalah salah satu komponen manusiawi dalam proses belajar mengajar, yaitu ikut berperan dalam usaha pembentukan sumber daya manusia yang potensial di bidang pembangunan. Oleh karena itu guru yang merupakan salah satu unsur di bidang kependidikan harus berperan secara aktif dan menempatkan kedudukannya sebagai tenaga professional, sesuai dengan tuntutan masyarakat yang semakin berkembang.

Guru merupakan orang yang memegang peran di dalam proses belajar mengajar, guru yang memimpin dan mengarahkan kegiatan belajar mengajar para siswanya, pengaruh peran guru terhadap siswanya sangat besar. Karena peran guru di dalam proses belajar mengajar sangat menentukan keberhasilan siswa dalam belajar.

Lain dengan halnya di SMPN 46 Kerinci, bahwasanya siswa yag mengalami kesulitan dalam belajar, dikarenakan kurangnya sarana pendukung untuk kegiatan siswa, bahkan ada siswa yang mengeluh belajar di SMPN 46 Kerinci.

Sebagaimana wawancara penulis dengan salah satu siswa Kelas VIII di bawah ini :"Saya merasa kewalahan belajar di SMPN 46 Kerinci, dikarenakan kurangnya alat pendukung untuk kegiatan kami, bahkan kami harus belajar dengan alat yang serba kekurangan, hal ini membuat kami merasa bosan dan tidak merasa di pedulikan dalam pembelajaran tersebut". 5

Dalam hal ini sudah jelas bahwa keluhan siswa di SMPN 46 Kerinci terhadap kesulitan belajar mereka harus diperhatikan oleh tenaga pendidik, alat pendukung sangatlah penting untuk membantu siswa dalam mengembangkan pengetahuanya.

Hal ini sesuai dengan wawancara penulis dengan salah seorang siswa SMPN 46 Kerinci : "Dalam mengikuti kegiatan belajar mengajar kami sangat membutuhkan alat pendukung lainnya untuk memperjelas pembelajaran dan juga untuk mengembangkan pengetahuan kami dalam bentuk pembelajaran". 6

Kebanyakan siswa kurang mengerti dalam pembelajaran Fisika, Biologi, dan Keterampilan, hal ini dikarenakan kurangya alat peraga ataupun alat pendukung lainnya untuk mempermudah siswa dalam menerima apa yang diperjelas oleh guru mata pelajaran tersebut. Seperti dalam mata pelajaran fisika kurangnya alat peraga yang tersedia di labor IPA, bahkan siswa harus menggunakan alat yang serba kekurangan, padahal dalam pembelajaran fisika siswa sangat membutuhkan alat peraga ang lengkap untuk memperjelas hasil

Kurniawan, Siswa Kelas VIII B SMP Negeri 46 Kerinci, Wawancara, Tanggal. 08 Oktober 2020.

Yuliana, Siswa Kelas VIII A B SMP Negeri 46 Kerinci, Wawancara, Tanggal. 08 Oktober 2020. 
ang mereka pelajari. Sebagaimana wawancara penulis dengan guru mata pelajaran Fisika : "Kami sebagai guru pembimbing dalam mata pelajarn fisika juga merasa bahwa alat kelengkapan ang ada di labor IPA sangat lah minim untuk siswa dalam menanggapi pelajaran yang kami terapkan, padahal untuk mempermudah siswa mengerti dalam pelajar fisika adalah dengan memperagakan langsung sesuai dengan materi yang kami ajarkan pada saat itu".

Dalam hal yang serba kekurangan untuk pembelajan fisika, siswa juga merasa kesulitan dalam penerimaan pembelajaran keterampilan, dikarenakan alat pendukung untuk pembelajaran tidak ada sama sekali. Seperti wawancara penulis dengan salah satu siswa SMPN 46 Kerinci :

Untuk pembelajaran keterampilan adalah pelajaran yang sangat menyenangkan dikarenakan banyaknya praktek untuk membuat segala macam keterampilan, akan tetapi hal ini membuat kami merasa sulit mengikuti praktek tersebut, dikarenakan ruang khusus praktek tidak ada di sini apa lagi alat peraga yang tidak memadai. ${ }^{8}$

Dalam pelaksanaan pembelajaran yang serba kekurangan alat pendukung ataupun alat peraga dapat membuat siswa mengeluh dalam belajar dan membuat mereka tidak ada konsentrasi dalam mengikuti pembelajaran tersebut. Hal ini dikatakan oleh guru Bimbingan Konseling SMPN 46 Kerinci

Saya sebagai guru Bimbingan Konseling sangat prihatin dengan kegiatan pembelajaran siswa dengan alat yang serba kekurangan, bahkan banyak siswa yang mengadu kepada saya bahwa mereka merasa bosan belajar dengan alat yang serba kekurangan sehingga mereka malas-malasan mengikuti pembelajaran tersebut.?

Sebagaimana dikemukakan oleh Kepala Sekolah SMPN 46 Kerinci: "Sebagai kepala sekolah saya menekankan kepada Guru Bimbingan Konseling untuk memperhatikan sisiwa yang tidak dapat mengikuti pelajaran dengan baik, guna untuk mengetahui apa penyebab siswa itu bisa tertinggal dalam pelajaran tersebut". 10

Dengan adanya laporan siswa kepada guru bimbingan konseling disinilah letak tugas guru bimbingan konseling dalam menanggapi permasalahan siswa dalam menerima pembelajaran dari guru tersebut.

Dalam mengikuti pembelajaran siswa banyak yang hilang konsentrasi dikarenakan alat peraga yang kurang untuk memperjelaskan kepada siswa secara mendetail tentang yang dipelajari padasaat itu. Hal ini dikatakan oleh bapak kepala SMPN 46 Kerinci : "Saya sebagai pimpinan disini dan juga sebagai guru mata pelajaran Biologi merasa sangat terganggu di saat

Elda, S.Pd Guru Mata Pelajaran Fisika SMP Negeri 46 Kerinci, Wawancara, 08 Oktober 2020

Ahmad, Siswa Kelas VIII B SMP Negeri 46 Kerinci, Wawancara, Tanggal. 08 Oktober 2020.

Liza Devita Heri, S.Pd Konselor SMP Negeri 46 Kerinci, Wawancara, Tanggal. 08 Oktober 2020 
menerapkan pembelajaran didepan kelas dikarenakan banyaknya siswa yang kurang konsentrasi dalam penjelasan saya, disaat saya tanya siswa tersebut mengatakan bahwa dia tidak jelas hanya dengan penjelasan saja bahkan membuat mereka bosan, mereka menginginkan praktek di labor IPA untuk penjelasan yang lebih detail". ${ }^{11}$

Dalam hal ini sudah jelas bahwa siswa kesulitan dalam menerima pembelajaran yang seharusnya langsung praktek tetapi masih dijelaskan dengan kata-kata di depan kelas oleh guru pembimbing tersebut. Seperti wawancara penulis dengan konselor di bawah ini :'Dalam mengikuti pelajaran yang ada di dalam kelas terus menerus padahal pelajaran tersebut harus dipraktekkan langsung dengan menggunakan alat peraga tersebut itu akan membuat siswa merasa jenuh dan bosan, dikarenakan tidak semua siswa dapat menyerap pelajaran hanya dengan penjelasan guru saja akan tetapi ada siswa yang dapat menyerap pelajaran dengan melihat langsung hasil praktek pelajaran tersebut."12

Berdasarkan hasil wawancara penulis dengan konselor dapat penulis simpulkan bahwa untuk mempermudah siswa dalam meneriam pelajaran dari guru mata pelajaran tersebut sangatlah membutuhkan alat peraga yang cukup, dikarenakan ada sebagian siswa yang tidak bisa menerima pelajaran tanpa melihat hasil praktek tersebut. Dalam pembelajaran guru tidak hanya sematamata mempunyai penguasaan terhadap bidang studi yang diajarkan. Sebagai pendidik, kepribadian guru turut mempengaruhi hubungannya dengan peserta didik. Kepribadian guru dapat dikatakan sangat memegang peranan dalam menjalankan tugasnya sebagai pendidik. Hubungan antara guru mata pelajaran dengan guru bimbingan konseling tidak bisa dipisahkan. Karena pada saat guru mata pelajaran tidak bisa menangani kasus siswanya maka guru bimbingan konselinglah yang harus menindak lanjutinya. Peserta didik hendaknya dapat dijaga. Konselor harus memahami jiwa anak didiknya dan dia juga harus mengetahui penyebab seorang anak didiknya tidak bergairah dalam belajar.

\section{Apakah Kendala Dan Faktor Pendukung Guru Bimbingan Konseling Dalam Mengatasi Kesulitan Belajar Siswa di SMPN 46 Kerinci.}

\section{a. Kendala yang dihadapi Guru Bimbingan Konseling.}

Guru Bimbingan Konseling merupakan faktor utama yang berperan aktif dalam meningkatkan kualitas siswanya. Karena Guru Bimbingan Konseling adalah tombak kesuksesan belajar siswa dalam peningkatan mutu belajar siswa. Maka dengan permasalahan yang terjadi tehadap siswa SMPN 46 Kerinci adalah tanggung jawab besar yang dipegang oleh Guru Bimbingan Konseling SMPN 46 Kerinci. Akan tetapi hal ini mendapat 
beberapa kendala yang harus dihadapi oleh guru bimbingan konseling dalam mengentaskan permasalahan belajar siswa, seperti kurangnya perhatian dari warga setempat untuk kemajuan SMPN 46 Kerinci, sarana prasarana yang tidak mendukung, kurangnya pengawasan alat peraga untuk SMPN 46 Kerinci.

Sebagaimana yang dikatakan oleh guru Bimbingan Konseling SMPN 46 Kerinci : Kendala yang harus kita perhatikan dalam pengentasan pembelajaran siswa pada pelajaran tertentu juga harus dengan dukungan masyarakat setempat sehingga membuat perhatian dari dinas pendidikan untuk kemajuan SMPN 46 Kerinci. ${ }^{13}$

Dalam hal ini juga disampaikan oleh salah seorang guru mata pelajaran Agama Islam SMPN 46 Kerinci : Memang betul apa yang dikatan oleh guru bimbingan konseling, bahwa untuk pengentasan permasalahan siswa harus adanya dukungan dari masyarakat, seperti sulitnya siswa dalam mempelajari baca tulis ayat al-qur'an, ini juga hal yang harus kami tingkatkan kerja sama dengan masyarat untuk mengirim siswa kami untuk belajar di masyarakat. ${ }^{14}$

Dari wawancara di atas sudah sangat jelas bahwa kerja sama guru di SMPN 46 Kerinci dengan masyarakat sangatlah penting dan sangat sangat erat untuk meningkatkan kualitas belajar siswa dan pengentasan belajar siswa. Hal ini sesuai wawancara penulis dengan salah seorang guru: Dalam menjalankan program bulanan yang dilakukan oleh guru Bimbingan Konseling memang dapat menunjang siswa dalam belajar yang baik, akan tetapi hal tersebut dapat membuat siswa tidak bisa membantu orang tuanya selepas pulang sekolah. ${ }^{15}$ Hal ini juga disampaikan oleh seorang guru Bimbingan Konseling: Hal yang membuat kurangnya alat peraga di SMPN 46 Kerinci adalah kurangnya pengawasan terhadap SMP 46 Kerinci, sehingga hal ini membuat saya sulit untuk menjangkau hubungan dengan intansi tertentu ${ }^{16}$.

Berdasarkan wawancara di atas, bahwa guru juga mendapat kesulitan pada layanan penguasaan konten terutama kurangnya waktu yang diberikan pada sore hari.

\section{b. Hal pendukung bagi guru Bimbingan Konseling}

Selain dari pada permasalahan yang harus dihadapi oleh guru bimbingan konseling untuk mengentaskan permasalahan siswa dalam pembelajaran, ada beberapa yag sangat mendukung program ataupun keinginan dari guru bimbingan konseling untuk menunjang pembelajaran siswa smpn 17 kerinci, seperti: adanya dukungan dari bapak kepala sekolah,

Liza Devita Heri, S.Pd Konselor SMP Negeri 46 Kerinci, Wawancara, Tanggal. 26

Oktober 2020

Denal Efendi, S.PdI, Guru PAI, Wawancara, 26 Oktobr 2020

Hanizar, S.Pd, Guru Bahasa Indonesia, Wawancara, 26 Oktobr 2020

Liza Devita Heri, S.Pd Konselor SMP Negeri 46 Kerinci, Wawancara, Tanggal. 26

Oktober 2020 
adanya kerja sama guru untuk mempermudah program bimbingan konseling.

Sebagaimana disampaikan oleh Guru Bimbingan Konseling SMPN 46 Kerinci : Saya merasa sangat terbantu dengan adanya dukungan dari kepala sekolah untuk memprogram rangkaian untuk mendapatkan alat peraga ataupun alat praktek di smpn 17 kerinci dan apalagi dengan adanya kerja sama yang baik dari guru mata pelajaran tersebut. ${ }^{17}$

Berdasarkan wawancara di atas, bahwa juga terdapat hal yang mendukung program dari guru bimbingan konseling untuk mengentaskan permasalahan siswa dalam proses pembelajaran. Dari kendala di atas yang telah disampaikan kepada penulis, dalam hal ini ada beberapa solusi untuk menghadapi hal-hal tersebut. Sebagaimana wawancara penulis dengan siswa: Kami sebagai siswa SMPN 17 Kerinci sangat mendukung dengan adanya program bulanan yang dilaksanakan oleh guru bimbingan konseling, terutama yang kami inginkan adalah labor praktek dan isi yang memadai untuk kami melakukan praktek langsung. ${ }^{18}$

Berdasarkan wawancara penulis dengan siswa bahwa siswa membutuhkan alat pendukung untuk mempermudahkan mereka mengikuti pembelajaran yang baik dan agar mudah di pahami.

\section{E. Strategi Guru Bimbingan Konseling Dalam Mengatasi Kesulitan Belajar Siswa di SMPN 46 Kerinci.}

Guru bimbingan konseling sangatlah penting keberadaanya di SMPN 46 Kerinci untuk mengatasi kesulitan belajar yang dihadapi oleh siswa kelas VIII. Hal ini sesuai yang dikatakan oleh kepala sekolah SMPN 46 Kerinci ; Saya merasa sangat membutuhkan peran dari guru bimbingan konseling dalam mengatasi kesulitan belajar siswa yang kami hadapi, dikarekan guru bimbingan konseling lah yang paling mengerti dengan keberadaan siswa untuk mengikuti pembelajaran vang kami terapkan, dikarenakan kebanyakan siswa suka mengadu atau curhat kepada guru Bimbingan Konseling tentang permasalahan mereka untuk mengikuti pembelajaran ${ }^{19}$ Disini sudah jelas bahwa guru bimbingan konseling sangatlah penting untuk mengatasi permasalahan siswa dalam mengikuti pembelajaran. Hal ini juga dikatakan oleh guru Fisika SMPN 47 Kerinci : "Saya sebagai guru fisika sangat membutuhkan bantuan guru bimbingan konseling dalam mengatasi kesulitan belajar siswa, dikarenakan bagi saya guru bimbingan konseling mengerti bagaimana cara menanggapi permasalahan seperti ini". ${ }^{20}$

Liza Devita Heri, S.Pd Konselor SMP Negeri 46 Kerinci, Wawancara, Tanggal. 26 Oktober 2020

Hermawan, Siswa SMP Negeri 46 Kerinci, Wawancara, 26 Oktober 2020

Zaini, S.Pd Kepala Sekolah SMP Negeri 46 Kerinci, Wawancara, 08 Oktober 2020.

Elda, S.Pd Guru Mata Pelajaran Fisika SMP Negeri 46 Kerinci, Wawancara, 08 Oktober 2020. 
Untuk mennggapi permasalah hal tersebut guru Bimbingan Konseling sangat lah dibutuhkan perannya dalam menuntaskan permasalahan siswa dalam mengikuti pembelajaran. Guru bimbingan konseling di SMPN 46 Kkerinci juga dijadikan tombak untuk kesuksesan siswa dalam menerima pelajaran dari mata pelajaran tersebut, maka untuk itu hal permasalahan yang terjadi saat ini di SMP N 46 kerinci harus di tuntaskan oleh guru bimbingan konseling.

Sebagaimana wawancara penulis dengan guru Bimbingan Konseling di SMPN 46 kerinci : "Sebagai guru bimbingan konseling saya merasa bahwa kasus yang dihadapi siswa pada saat ini adalah kesulitan mereka dalam mengikuti pembelajaran dan hal seperti ini juga merupakan tanggung jawab saya sebagai guru bimbingan konseling, hal ini juga telah di sampaikan oleh beberapa siswa kepada saya dan juga kepala sekolah memberikan tanggung jawab permasalahan ini kepada saya" ${ }^{21}$

Untuk meningkatkan pembelajaran siswa guru bimbingan konseling berperan aktif terhahadap kelancaran siswa menerima pelajaran dari guru mata pelajaran tersebut. Hal lain dikatakan oleh guru bimbingan konseling di SMPN 46 Kerinci : "Memang tanggung jawab saya sebagai guru bimbingan konseling sangatlah besar apalagi hal ini menyangkut dengan kesulitan belajar siswa dalam mengikuti pelajaran, maka saya memang harus selalu memperhatikan siswa saya bagaimana perkembangan mereka untuk mengikuti pelajaran agar sekolah kami tidak ketinggalan dengan sekolah lain", ${ }^{22}$

Dari hasil wawancara penulis dengan guru bimbingan konseling untuk menanggapi permasalahan seperti ini, guru bimbingan konseling mengambil sikap seperti :

1. Guru bimbingan konseling memanggil beberapa orang siswa kelas VIII dan guru mata pelajaran tersebut guna untuk mengetahui permasalahan yang lebih detai lagi, agar permasalahan bisa di atasi dengan mudah. Sebagaimana yang dikatakan oleh guru Bimbingan Konseling SMPN 46 Kerinci : Agar permasalahan ini tidak menyimpang terlalu jauh ataupun permasalahan menjadi tidak konkrit saya memanggil siswa dan guru mata pelajaran untuk mengetahui permasalahan yang lebih detail lagi, agar mempermudah saya untuk mengentaskan permasalahan ini. ${ }^{23}$

Disini sudah jelas bahwa menjadi guru bimbingan konseling haruslah jeli dengan permasalahan siswa agar kita bisa menyelesaikan permasalahan yang dihadapi oleh siswa tersebut. Hal ini juga dikatan oleh guru bimbingan konseling SMPN 46 Kerinci: "Dengan memanggil salah satu siswa saya mengetahui dengan jelas apa permasalahan siswa sebenarnya dan apa yang

\footnotetext{
$21 \quad$ Liza Devita Heri, S.Pd Konselor SMP Negeri 46 Kerinci, Wawancara, Tanggal. 08 Oktober 2020

22 Liza Devita Heri, S.Pd Konselor SMP Negeri 46 Kerinci, Wawancara, Tanggal. 08 Oktober 2020

23 Liza Devita Heri, S.Pd Konselor SMP Negeri 46 Kerinci, Wawancara, Tanggal. 08 Oktober 2020
} 
mereka perlukan untuk meningkatkan penunjang belajar mereka agar mereka tidak mengalami kesulitan dalam mengikuti pelajaran". ${ }^{24}$

Tugas seorang guru bimbingan konseling juga harus ada pendekatan dengan yang baik agar mereka berani dalam melaporkan permasalahan mereka. Apabila pendekatan seorang guru bimbingan konseling telah baik dengan siswa maka disinilah terjadi komunikasi yang baik antara siswa dengan guru bimbingan konseling.

2. Guru bimbingan konseling berkonsultasi dengan waka sarana prasarana guna utuk mengusulkan alat peraga ke pada dinas pendidikan demi untuk kemajuan pembelajaran siswa SMPN 46 Kerinci. Hal ini disampaikan oleh guru Bimbingan Konseling SMPN 46 Kerinci : Untuk tindakan selanjutnya saya bekerja sama dengan waka sarana prasarana untuk melakukan rancangan usulan bantuan kepada dinas pendidikan, agar dinas pendidikan memahami permasalahan yang dialami oleh siswa SMPN 46 Kerinci. $^{25}$ Sebagai guru bimbingan konseling dan juga dikatakan sebagai tombak kesuksesan belajar siswa maka untuk itu guru bimbingan konseling harus mempunyai jangkauan luas kepada pihak yang bersangkutan agar mempermudah penyelesaian permasalahan yang terjadi, apalagi terhadap sesama guru yang mengajar di SMPN 46 Kerinci, kerja sama guru sangatlah penting untuk kesuksesan pembelajaran. Sebagaimana dikatakan oleg guru bimbingan konseling SMPN 46 Kerinci : Untuk pengentasan permasalahan siswa maka saya guru bimbingan konseling juga harus mempunyai pendekatan yang kuat dengan waka sara prasarana untuk memperhatikan fasilitas pendukung belajar siswa agar mereka tidak ketinggalan dengan sekolah yang lain. ${ }^{26}$

Untuk itu guru bimbingan konseling sudah jelas harus mempunyai pendekatan yang kuat dengan pihak yang bersangkutan dalam pengentasan permasalahan siswa.

3. Sebagai guru bimbingan konseling sikap yang sangat penting di ambil untuk kelancaran belajar siswa pada mata pelajaran tersebut adalah memberikan motifasi kepada siswa agar tidak bermalas-malasan belajar walaupun dengan alat peraga yang serba kekurangan. Dalam pemberantasan permasalahan siswa terhadap beberapa pelajaran maka untuk itu guru bimbingan konseling sangat berperan aktif kepada siswa dan juga kepada guru mata pelajaran tersebut. Hal ini sebagaimana yang disampaikan oleh salah seorang siswa : Saya sangat senang dengan adanya kerja sama guru bimbingan konseling dengan guru mata pelajaran yang bersangkutuan, karena dengan adanya kerja sama tersebut kami sebagai siswa bisa mempunyai motifasi untuk tidak bermalas-malasan. ${ }^{27}$

\footnotetext{
$24 \quad$ Liza Devita Heri, S.Pd Konselor SMP Negeri 46 Kerinci, Wawancara, Tanggal. 08 Oktober 2020

25 Liza Devita Heri, S.Pd Konselor SMP Negeri 46 Kerinci, Wawancara, Tanggal. 08 Oktober 2020

26 Liza Devita Heri, S.Pd Konselor SMP Negeri 46 Kerinci, Wawancara, Tanggal. 08 Oktober 2020

27 Kiki Yuliani, Siswa kelas VIII C SMP Negeri 46 Kerinci. Wawancara, 08 Oktober 2020
} 
Dalam proses belajar mengajar kerja sama guru mata pelajaran dengan guru bimbingan dan konseling sangatlah penting terutama terhadap permasalahan belajar siswa. Semua guru pasti ingin melihat siswanya sukses didalam pelajarannya, tidak ada seorang guru yang ingin menjerumuskan siswanya, bahkan banyak kita lihat ada guru yang rela memberikan jam tambahan tersendiri. Kerja sama yang dilakukan guru bimbingan dan konseling dengan guru mata pelajaran sangatlah baik kepada para siswa dalam meningkatkan kualitas dan prestasi para peserta didik.

Guru bimbingan konseling merupakan faktor utama yang berperan aktif dalam meningkatkan kualitas siswanya. Karena berhasil tidaknya siswa belajar tergantung pada guru.

Hal ini juga disampaikan oleh guru bimbingan konseling SMPN 46 Kerinci : "Untuk meningkatkan pengentasan belajar siswa yang memberiakn motifasi yang kuat kepada siswa agar mereka mengerti pentingnya pendidikan walaupun dengan alat yang serba kekurangan, agar mereka mau belajar dengan sunggh-sungguh dan tidak terpaku dengan alat yang kurang memadai".28

Jelas kita lihat dari wawancara diatas bahwa seorang guru bimbingan konseling juga harus mampu membuat siswa mengerti dengan pendidikan dan harus mampu menguasai situasi.

4. Dalam peningkatan mutu pelajaran siswa, guru Bimbingan Konseling adalah sebagai pemegang layanan pembelajaran, maka untuk itu guru Bimbingan Konseling sangat memperhatikan bagaimana perkembangan siswanya, guru Bimbingan Konseling di SMPN 46 Kerinci memberikan kebebesan kepada siswanya untuk membuka wawasan, seperti mengadakan studi banding kepada sekolah lain guna untuk mengetahui sejauh mana pelajaran yang harus mereka kejar.

Hal ini disampaikan oleh guru bimbingan konseling SMPN 46 Kerinci :

Saya memberikan kebesan bagi siswa untuk mengikuti studi banding ke sekolah lain agar mereka mengetahui sejauh mana perkembangan pelajaran mereka dengan sekolah lain. ${ }^{29}$

5. Guru Bimbingan Konseling di SMPN 46 Kerinci mendatangkan alat peraga pinjaman dari instansi tertentu, ini juga merupakan program bulanan dari guru bimbingan konseling untuk peningkatan mutu pembelajaran di SMPN 46 Kerinci. Sebagaimana disampaikan oleh guru Bimbingan Konseling : "Dengan kurangnya alat peraga atau alat praktek di SMPN 46 kerinci, maka untuk itu saya sebagai guru bimbingan konseling atau yang bertpegang teguh untuk kelancaran balajar siswa saya membuat program bulanan yaitu

28 Liza Devita Heri, S.Pd Konselor SMP Negeri 17 Kerinci, Wawancara, Tanggal. 08 Oktober 2020

29 Liza Devita Heri, S.Pd Konselor SMP Negeri 17 Kerinci, Wawancara, Tanggal. 08 Oktober 2020 
mendatangkan alat peraga atau alat praktek pinjaman kepada instansi lain agar setidaknya siswa dapat mengenal alat peraga tersebut.",30

Berdasarkan wawancara penulis dengan guru bimbingan konseling bahwa pertian guru bimbingan konseling terhadap permasalahan siswa sangatlah dekat dan begitumembantu siswa. Hal ini juga di sampaikan salah seorang siswa SMPN 46 Kerinci :"Dengan adanya program bulanan dari guru Bimbingan Konseling yaitu mendatangkan alat peraga atau alat praktek pinjaman kami merasa terbantu untuk mengenal alat tersebut walaupun tidak begitu mndalam, tapi setidaknya kami sudah mengetahui bagaimana cara menggunakan alat tersebut". ${ }^{31}$

Berdasarkan wawancara diatas penulis dapat mengambilan kesimpulan bahwa mendatangkan alat peraga ataupun alat praktek pinjaman sangatlah berguna bagi siswa smpn 17 kerinci.

6. Di SMPN 46 Kerinci Guru Bimbingan Konseling sangatlah berpegang teguh kepada asas-asas bimbingan konseling yang berlaku, dalam menanggapi permasalahan seperti ini guru bimbingan konseling juga megadakan layanan pembelajaran terhadap siswa guna untuk mempermudah siswa dalam menyerap pelajaran yang tertinggal dalam hal praktek. Hal ini disampaikan oleh guru Bimbingan Konseling : Dalam peningkatan pelajaran siswa saya juga menggunakan layanan pembelajaran yang dilakukan pada sore hari dengan mendatangkan halyang bersangkutan, seperti contohnya jika mereka pelajarannya harus praktek biolagi tentang penelitian alat kelamin maka saya harus mendatangkan seorang perawat ataupun dokter, hal ini juga atas izin dari kepala sekolah dan guru yang bersangkutan. ${ }^{32}$

Dalam hal ini sudah jelas bahwa layanan pembelajaran yang dilakukan oleh Guru Bimbingan Konseling sangatlah membantu siswa dalam pelajaran tertentu. Hal seperti adalah pendukung untuk pengentasan permasalahan yang terjadi di SMPN 17 Kerinci.

\section{F. Penutup}

Berdasarkan uraian dan penjelasan tersebut diatas dapat disimpulkan bahwa strategi Guru Bimbingan Konseling dalam mengatasi kesulitan belajar siswa di SMP Negeri 46 Kerinci adalah:

1. Bentuk kesulitan belajar siswa di SMPN 46 Kerinci sudah sangat jelas bahwa mereka kekurangan alat pendukung ataupun alat penunjang lainnya, seperti kurangnya alat peraga atau praktek untuk mereka mendalami pelajaran.

2. Faktor penghambat guru bimbingan konseling dalam pengentasan permasalan siswa adalah kurangnya dukungan dari masyarakat setempat untuk bekerja sama dalam meningkatkan kualitas belajar siswa. Akan tetapi ada juga yang menjadi hal pendukung bagi guru

Liza Devita Heri, S.Pd Konselor SMP Negeri 17 Kerinci, Wawancara, Tanggal. 26 Oktober 2020

31 Riki, Siswa Kelas VIII A SMP Negeri 17 Kerinci. Wawancara, 26 Oktober 2020

Liza Devita Heri, S.Pd Konselor SMP Negeri 46 Kerinci, Wawancara, Tanggal. 26 Oktober 2020 
bimbingan konseling yaitu adanya kerja sama yang baik guru bimbingan konseling dengan waka sarana prasarana.

3. Untuk pengentasan permasalahan siswa SMPN 46 kerinci terutama di kelas VIII guru bimbingan konseling membuat strategi seperti : memberiakn motifasi yang baik kepada siswa, memanggil siswa keruangan bimbingan konseling untuk mengetahui permasalahan yang sebenarnaya,

\section{Referensi}

Abimanyu, Soli, (1991), Tekhnik dan Laborratorium Konseling, Jakarat: Proyek Pendidikan dan Tenaga Tekhnik

Andi Mapiare, (1995), Pengantar Bimbingan konseling di Sekolah, Surabaya: Usaha Nasional. .

Desiana, (2012), Metode Penelitian, Sungai Penuh : STAIN Kerinci Press

Departemen Pendidikan Nasional, (2008), Kamus Bahasa Indonesia, (Jakarta : Departemen Pendidikan Nasional.

Departemen Pendidikan Nasional, (2003), Undang-undang Republik Indonesia Nomor 20 Tahun 2003 Sistem Pendidikan Nasional, Jakarta : Departemen Pendidikan Nasional,

Dharma Surya, (2008) Proses Penelitian, Jakarta : PMTK.

Hallen, (2005), Bimbingan dan Konseling, Padang: PT. Ciputat Press

Ihkrom, (2009), Psikopatologi Kesehatan Mental Sufistik, Semarang : Walinsongo Press.

Juntika, Ahmad, Nurihsan, (2005), Strategi Layanan Bimbingan dan Konseling, Bandung: PT. Refika Aditama 